Journal of Computer Science 7 (9): 1335-1337, 2011

ISSN 1549-3636

(C) 2011 Science Publications

\title{
Finite Element Study of the Stress Response of Bi-Directional Corrugated-Strip Core Sandwich Beam
}

\author{
${ }^{1}$ Suphattharachai Chomphan and ${ }^{2}$ Manit Leekitwattana \\ ${ }^{1}$ Department of Electrical Engineering, Faculty of Engineering at Si Racha, \\ ${ }^{2}$ Department of Naval Architecture and Marine Engineering, \\ International Maritime College, \\ ${ }^{2}$ Kasetsart University, 199 M.6, Tungsukhla, Si Racha, Chonburi, 20230, Thailand
}

\begin{abstract}
Problem statement: In engineering design, stress affects the size of structural member. A suitable topology of structure should be designed to optimize the stress. Approach: This study presents an alternative topology of truss-like core sandwich beam referred to here as bi-directional corrugated-strip core topology. A finite element method is used to study the stress response of three point loaded truss-like core sandwich beams. Two kinds of core topologies: a truss core and a bidirectional corrugated-strip core are chosen to be analyzed and compared to each other. Results: The results showed that the bi-directional corrugated-strip core topology provided less surfaced normal stress than the truss core topology. Conclusion: From the finding, the stress of truss-like core sandwich beam can be optimized by arranging the core in the alternative bidirectional corrugated-strip core topology.
\end{abstract}

Key words: Sandwich beam, stress response, truss core, core topology, engineering design, finite element software, finite element models, alternative bi-directional, truss-like core sandwich

\section{INTRODUCTION}

In recent design of engineering structures, the need for structures with optimized stress responses is increasing. To deliver such structures, engineering designers may design a new structural topology such as a sandwich structure.

In truss-like core sandwich construction, a core formed in various corrugation profiles may be arranged in either a one-way or a two-way pattern. In addition, the core can also be designed in various advanced patterns such as an offset-corrugated core (Ray, 1995), a bi-directional corrugated core (Ray, 1996), a cross corrugated core (Ray, 1997) and a bi-directional corrugated-strip core (Leekitwattana et al., 2011; Paknejad et al., 2009; Kumar and Singh, 2010; Souiyah et al., 2009; Thomas and Dozier, 2010; Urgessa, 2009).

This study aims to presents an alternative to the truss-like core sandwich beam in which a bi-directional corrugated-strip core is proposed. This study also aims to outline the advantage in stress response of this alternative in comparison with a truss core.

\section{MATERIALS AND METHODS}

Finite element software: The commercial finite element software ANSYS Release 11 is used in this study. The ANSYS is run under the operating software MS Windows XP Professional Version 2002. The hardware condition is a desktop computer with Intel ${ }^{\circledR}$ Core $^{\mathrm{TM}} 2$ CPU $6600 @ 2.40 \mathrm{GHz}$ and $1.98 \mathrm{~GB}$ of RAM.

Finite element models: Three-dimensional finite element models of bi-directional corrugated-strip core sandwich beam, as shown in Fig. 1, are analyzed. The sandwich beam consists of the top and bottom steel faceplates and a series of corrugated-strip core. These parts are modeled using the SOLID45 element type-an eight-node element having three degrees of freedom in nodal translations at each node. In this study, the typical 2-mm finite element mesh size is used. The connections between the faceplates and core elements are defined as fully rigid.

The sandwich beam, as shown in Fig. 1, has simply supports at the lines 1-1' and 2-2'. An additional constraint boundary condition is set up along the lines 33 ' and 4-4' to reduce the local deformation effect beneath the loading line 5-5', which is subjected to a unit transverse force per unit width of the sandwich beam (Table 1).

In addition to the bi-directional corrugated-strip core, the truss core, as shown in Fig. 2a, is also investigated and compared.

Corresponding Author: Suphattharachai Chomphan, Department of Electrical Engineering, Faculty of Engineering at Si Racha, Kasetsart University, 199 M.6, Tungsukhla, Si Racha, Chonburi, 20230, Thailand 


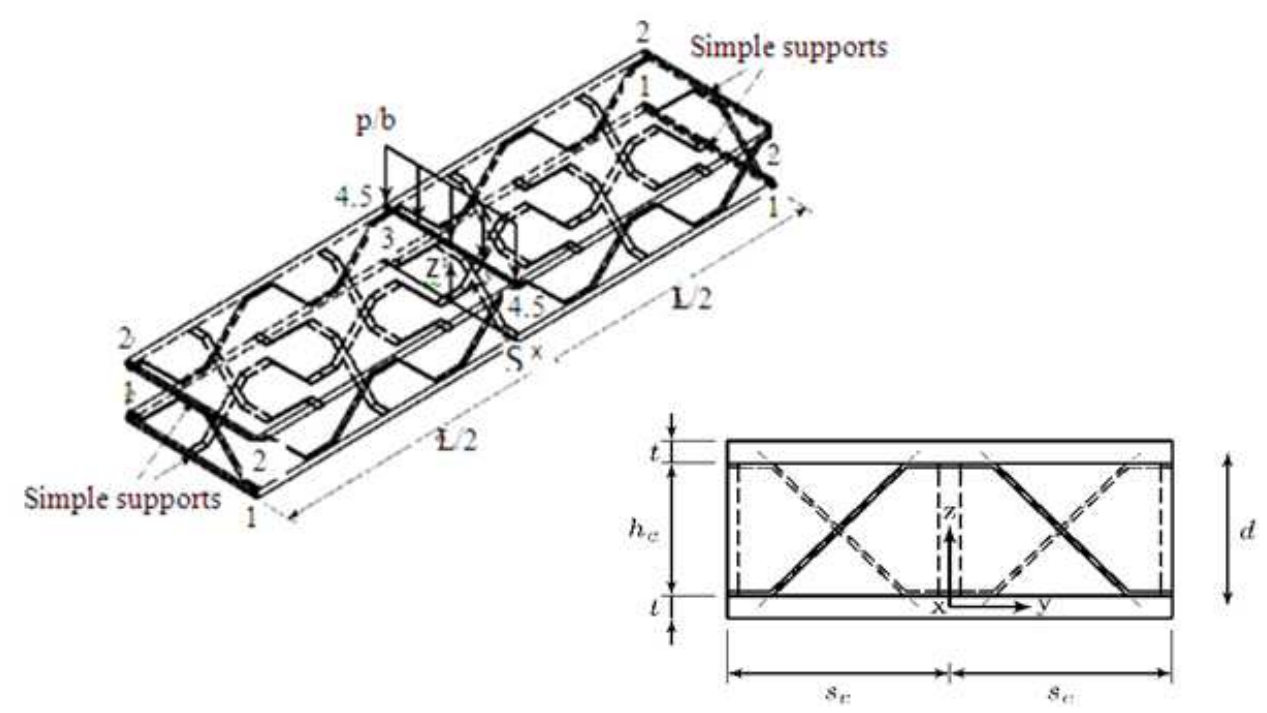

Fig. 1: A finite element model of three-point loaded bi-directional corrugated-strip core sandwich beam

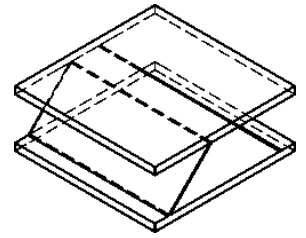

(a)

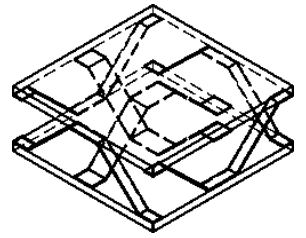

(b)

Fig. 2: A model of (a) truss core and (b) bi-directional corrugated-strip core

Table 1: Configuration of sandwich beams

\begin{tabular}{lrc}
\hline Dimensions & Value & Unit \\
\hline Length of sandwich beam, $\mathrm{L}$ & 3200 & $\mathrm{mM}$ \\
Width of sandwich beam, $\mathrm{b}$ & 100 & $\mathrm{mM}$ \\
Thickness of sandwich faceplate, $\mathrm{t}$ & 12 & $\mathrm{mM}$ \\
Depth of sandwich core, $\mathrm{h}_{\mathrm{c}}$ & 120 & $\mathrm{mM}$ \\
Width of core plate, $\mathrm{b}_{\mathrm{c}}$ & 25 & $\mathrm{mM}$ \\
Thickness of core plate, $\mathrm{t}_{\mathrm{c}}$ & 2 & $\mathrm{mM}$ \\
Half-length of corrugated unit cell, $\mathrm{S}_{\mathrm{c}}$ & 160 & $\mathrm{mM}$ \\
Length of flat leg of core plate, $\mathrm{f}_{\mathrm{c}}$ & 20 & $\mathrm{mM}$ \\
\hline
\end{tabular}

Table 2: Physical properties of steel

\begin{tabular}{lll}
\hline Properties & Value & Unit \\
\hline Yield Stress, $\mathrm{f}_{\mathrm{y}}$ & 355 & $\mathrm{~N} \mathrm{mM}^{-2}$ \\
Modulus of Elasticity, $\mathrm{E}_{\mathrm{s}}$ & 206,000 & $\mathrm{~N} \mathrm{mM}^{-2}$ \\
Poisson's Ratio, $\mathrm{V}_{\mathrm{s}}$ & 0.30 & \\
\hline
\end{tabular}

Material properties of steel: In this finite element study, the steel with perfectly elastic-plastic property is used. In the ANSYS, this material property of steel is defined using the bi-linear model. The tension and compression behaviors of steel are assumed the same. The physical properties of steel are defined in Table 2.

\section{RESULTS}

Based on the finite element method presented in the materials and methods section, the normal stress, $\sigma_{y}$, at the surface of the top face plate of sandwich beam with two core topologies, i.e., the truss core topology and the bi-directional corrugated-strip core topology, obtained from the ANSYS are presented in Fig. 3.

In Fig. 3, only left-side a half sandwich beam is presented, i.e., any point of the sandwich beam locates in the range of $0 \leq y \leq 1$. Due to the symmetry of the beam, this figure can present the right-side a half sandwich beam.

\section{DISCUSSION}

In comparison, it can be seen that the response of the normal stress, $\sigma_{y}$, of the bi-directional corrugatedstrip core is similar to the response of the truss core. Both responses distribute in the zigzag pattern along the top face plate.

It can be seen from Fig. 3 that, however, the surfaced normal stress, $\sigma_{y}$, at the upper peak of each unit cell of the bi-directional corrugated-strip core sandwich beam is significantly less than the stress $\sigma_{\mathrm{y}}$ at the same peak of the truss core sandwich beam. Compared with the truss core, the stress $\sigma_{\mathrm{y}}$ at, for example, $y \sim 140$ is about sixty per cent less. This may imply that introducing the core in the bi-directional corrugated-strip core format can optimize the surfaced normal stress, $\sigma_{y}$. Consequently, the thickness $t$ of the top face plate of this sandwich beam can be reduced. 


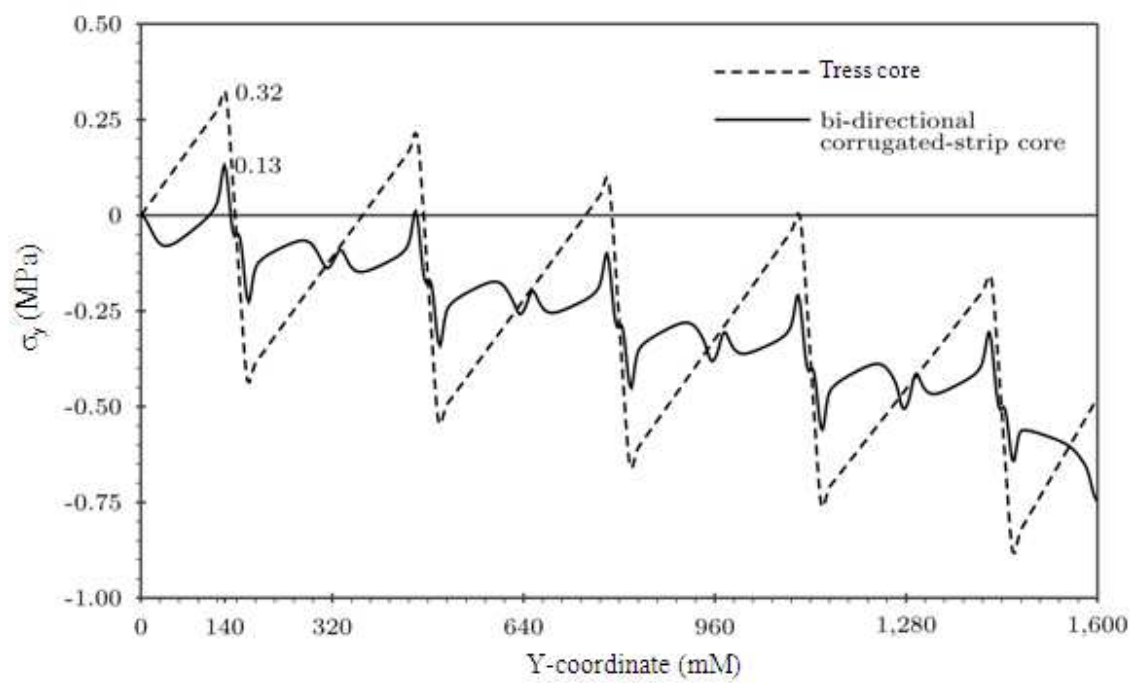

Fig. 3: Plot of the normal stress, $\sigma_{y}$, at the surface of the top face plate

Compared with the truss core, the thickness $t$ of the bi-directional corrugated-strip core sandwich beam can be less than the thickness $t$ of the truss core sandwich beam.

\section{CONCLUSION}

This study presents the alternative core topology to the truss-like core sandwich beam. The alternative core topology is referred to here as the bi-directional corrugated-strip core is presented. The surfaced normal stress response of three-point loaded bi-directional corrugated-strip core sandwich beam is studied using the finite element software ANSYS. The stress response of the bi-directional corrugated-strip core sandwich beam is compared with the stress response of the truss core sandwich beam. It is found that the sandwich beam with bi-directional corrugated-strip core topology can provide less normal stress at the surface of the top face plate of the sandwich beam in comparison with the truss core topology. From the finding, therefore, the normal stress of the truss-like core sandwich beam can be optimized by arranging the core in the alternative bidirectional corrugated-strip core topology.

\section{REFERENCES}

Kumar, P.R. and A.K. Singh, 2010. Web structure mining: exploring hyperlinks and algorithms for information retrieval. Am. J. Applied Sci., 7: 840845. DOI: 10.3844/ajassp.2010.840.845
Leekitwattana, M., S.W. Boyd and R.A. Shenoi, 2011. Evaluation of the transverse shear stiffness of a steel bi-directional corrugated-strip-core sandwich beam. J. Constr. Steel Res., 67: 248-254. DOI: 10.1016/J.JCSR.2010.07.010

Paknejad, F., M. Mirakhori, M.J. Al-Ahmadi, M.R. Tookalo and A.R. Pazoki et al., 2009. Physiological response of soybean (Glycine $\max$ ) to foliar application of methanol under different soil moistures. Am. J. Agric. Biol. Sci., 4: 311-318. DOI: 10.3844/ajabssp.2009.311.318

Ray, H., 1995. Offset Corrugated Sandwich Construction. http://www.freepatentsonline.com/H001481.html

Ray, H., 1996. Bi-directionally Corrugated Sandwich Construction. Patentstorm.

Ray, H., 1997. Panel having Cross-Corrugated Sandwich Construction. Patentstorm.

Souiyah, M., A. Muchtar, A. Alshoaibi and A.K. Ariffin, 2009. Finite element analysis of the crack propagation for solid materials. Am. J. Applied Sci., 6: 1396-1402. DOI: 10.3844/ajassp.2009.1396.1402

Thomas, M. B. and L. Dozier, 2010. Finite element modeling of transient temperatures in a smallcaliber projectile. Am. J. Eng. Applied Sci., 3: 355362. DOI: 10.3844/ajeassp.2010.355.362

Urgessa, G.S., 2009. Finite element analysis of composite hardened walls subjected to blast loads. Am. J. Eng. Applied Sci., 2: 804-811. DOI: 10.3844/ajeassp.2009.804.811 